\title{
Chemometric Methods for Studying the Relationships Between Trace Elements in Laryngeal Cancer and Healthy Tissues
}

\author{
R. Dobrowolski • J. Klatka • D. Brodnjak-Voncina • \\ A. Trojanowska • D. Myśliwiec • J. Ostrowski • M. Remer
}

Received: 16 April 2014 / Accepted: 8 May 2014 / Published online: 18 May 2014

(C) The Author(s) 2014. This article is published with open access at Springerlink.com

\begin{abstract}
A quick and reliable method for the evaluation and classification of two types of tissues is presented. Several chemometric methods were applied to evaluate multivariate data of the tissue samples with respect to the content of trace elements. The content of $\mathrm{Pb}, \mathrm{Al}, \mathrm{Zn}, \mathrm{Cd}$, $\mathrm{Cu}, \mathrm{Ni}$ and $\mathrm{Co}$ was determined in samples of healthy and cancerous tissue obtained from 26 patients. Determination was done at milligram/kilogram level with inductively coupled plasma optical emission spectrometry (ICP-OES) and atomic absorption spectroscopy (AAS) techniques. Contents of trace metals in studied tissues are not normally distributed; however, normal distribution was confirmed
\end{abstract}

The authors certify that they have no affiliations with or involvement in any organization or entity with any financial interest (such as honoraria; educational grants; participation in speakers' bureaus; membership, employment, consultancies, stock ownership or other equity interest and expert testimony or patent-licensing arrangements) or non-financial interest (such as personal or professional relationships, affiliations, knowledge or beliefs) in the subject matter or materials discussed in this manuscript.

All other Authors have read the manuscript and have agreed to submit it in its current form for consideration for publication in the Journal.

R. Dobrowolski

Faculty of Chemistry, Department of Analytical Chemistry and Instrumental Analysis, Maria Curie-Skłodowska University,

20-031 Lublin, Poland

\section{J. Klatka}

Department of Otolaryngology, Medical University, 20-059 Lublin,

Poland

D. Brodnjak-Voncina

Faculty of Chemistry and Chemical Engineering, University of

Maribor, Smetanova 17, 2000 Maribor, Slovenia

\section{A. Trojanowska}

Department of Radiology, Medical University, 20-059 Lublin,

Poland for log values. There is a statistically significant difference in the content of $\mathrm{Zn}, \mathrm{Cd}, \mathrm{Cu}$ and $\mathrm{Al}(p<0.01)$ and $\mathrm{Ni}$ and $\mathrm{Co}$ $(p<0.05)$ when healthy tissue is compared to cancerous one. Correlation between contents of trace elements for studied tissues was positive; the highest was found between $\mathrm{Zn}$ and $\mathrm{Cu}$. A chemometric methodology seems to be a promising tool for classifications of the tissue samples.

Keywords Chemometrics $\cdot$ Laryngeal cancer $\cdot$ Trace elements $\cdot$ ICP-OES $\cdot$ AAS

\section{Myśliwiec $(\square)$}

Faculty of Chemistry, Department of Radiochemistry and Colloid Chemistry, Maria Curie-Skłodowska University, 20-031 Lublin, Poland

e-mail: d.k.mysliwiec@gmail.com

J. Ostrowski

Analytical Department, Fertilizers Research Institute, Al. Tysiąclecia

Państwa Polskiego 13A, 24-110 Puławy, Poland

M. Remer

Department of Otolaryngology, District Hospital, 22-400 Zamość, Poland 


\section{Introduction}

The human body is a very complex structure and an appropriate concentration of trace elements (the contents of which is less than $0.01 \%$ of total body weight) is very important for its optimal operation. This is because they play an important role in numerous biochemical processes [1], e.g. zinc and copper are necessary for the proper functioning of the immune system $[2,3]$. In most cases, action of those elements is based on activation and/or inhibition of certain enzymes, e.g. by changing permeability of cell membranes [4]. Although trace elements are necessary to preserve a general body homeostasis, recent studies suggest that the excessive exposure to some of them may act as pathogenic factors. Few authors have studied the relationship between a concentration of some elements in human tissue and occurrence of certain diseases, mostly cancer [1, 4-8]. Moreover, Arita and Costa [9] and Salnikov and Zhitkovich [10] have published reviews concerning genetic and epigenetic mechanisms of carcinogenesis and carcinogenic properties of some elements, to which the human body might be exposed [11-13]. Study of this topic is extremely important because of progressing industrialization of human habitations and enhanced risk of exposure.

There are two main mechanisms responsible for element epigenetics: DNA methylation and posttranslational modification of histones [9]. Currently, it is believed that cancer is a consequence of abnormal and 'disturbed' DNA methylation - in most cases, global methylation is lowered while locally, it may be increased [14]. Recent studies revealed that epigenetic mechanisms are connected related to many elements such as nickel $[9,15,16]$, chromium $[9,10]$, cobalt $[10,17]$, cadmium [18] and copper [19]. Due to the fact that epigenetic mechanism may lead to cancer, one can postulate that concentration of the mentioned elements might be different in cancer cells as compared to the healthy ones in the same tissue.

In the presented paper, we have analysed concentrations of lead, cobalt, zinc, aluminium, cadmium, copper and nickel in laryngeal cancer and laryngeal healthy tissue. Complex statistical analysis of this data set is performed. Finally, the hypothesis claiming that concentration of analysed elements may be used as a diagnostic tool is evaluated.

\section{Materials and Methods}

We may point out two main aims of the presented paper. Firstly, we wanted to quantify information about a single group of patients, namely, smokers diagnosed with larynx cancer. Secondly, we have compared data from two setsconcentration of trace elements in tissues classified as cancerous and in the one supposed to be healthy. The study was conducted on 26 samples obtained from squamous cell laryngeal carcinoma and 26 corresponding cancer-free laryngeal tissues from the same male patients (44 to 76 years old, average age 62) after total laryngectomy. The patients were treated in the Department of Otolaryngology at the Medical University of Lublin. Patients who were taking microelements as supplements to their diet were excluded from the study. Samples of laryngeal tissues were weighed (about $0.5 \pm$ $0.001 \mathrm{~g}$ ) and digested in $3 \mathrm{ml}$ of Suprapur nitric acid (Merck, Germany) using the closed mineralization system Mars 5 (CEM, USA). Mineralization parameters were as follows: final temperature $195^{\circ} \mathrm{C}$, pressure $260 \mathrm{psi}$ and time of mineralization $8 \mathrm{~min}$. Following the mineralization, the residue was transferred to polyethylene volumetric flasks $(25 \mathrm{ml})$ and filled to volume with bidistilled water. The total content of the elements was determined by inductively coupled plasma optical emission spectrometry (ICP-OES) using a sequential spectrometer, model Liberty II AX (Varian, Australia). In all cases, where concentrations were below or close to limit of detection, concentrations were determined with an atomic absorption spectroscopy (AAS) using multiple injection system of Varian SpectrAA 800 spectrometer. The concentration of elements in the studied material was calculated on a dry tissue basis. In order to determine a calculation factor, another portion of laryngeal tissues was dried to a constant mass at $105^{\circ} \mathrm{C}$ using a laboratory dryer, model SML 35/250 (Zelmet, Poland); average dry mass was $27 \%$ of the initial. The applied analytical procedure was validated using a certified reference material (CRM) - contents are traceable to a beef liver NCS ZC85050. The data obtained for CRM are in good agreement with certified values that were confirmed by the method described by Linsinger [20]. The precision of determination of all elements by the method presented can be regarded as acceptable.

Therefore, the results of determinations of trace elements content for both types of tissue were analysed statistically [21-23].

\section{Results}

The concentrations of all analysed elements are summarized in Table 1.

\section{Statistical Analysis}

The results of all descriptors, namely, concentrations of seven elements in the two types of tissues (laryngeal carcinoma and healthy laryngeal tissue) have been investigated by different chemometric methods: the basic statistical methods for the determination of mean and median values, standard deviations, minimal and maximal values of measured variables and their mutual correlation coefficients. Statistical tests, correlation analysis, cluster analysis (CLU) principal component 
Table 1 The concentrations of all analysed elements

\begin{tabular}{lcc}
\hline & \multicolumn{2}{l}{ Concentration $(\mathrm{mg} / \mathrm{kg})$} \\
\cline { 2 - 3 } & Healthy tissue & Cancer tissue \\
\hline $\mathrm{Pb}$ & $0.196 \pm 0.068$ & $0.119 \pm 0.048$ \\
$\mathrm{Co}$ & $0.033 \pm 0.020$ & $0.006 \pm 0.007$ \\
$\mathrm{Zn}$ & $55.2 \pm 3.7$ & $32.4 \pm 3.1$ \\
$\mathrm{Al}$ & $2.28 \pm 1.02$ & $0.55 \pm 0.16$ \\
$\mathrm{Cd}$ & $0.720 \pm 0.205$ & $0.327 \pm 0.131$ \\
$\mathrm{Cu}$ & $3.80 \pm 0.84$ & $2.30 \pm 0.28$ \\
$\mathrm{Ni}$ & $0.188 \pm 0.102$ & $0.060 \pm 0.042$ \\
\hline
\end{tabular}

analysis (PCA) and linear discriminant analysis (LDA) were employed to analyse the differences between two types of tissues. All calculations and plots in the following section were done with the Statgraphics Centurion 10.0 and SPSS IBM Statistics 21. Microsoft Excel was utilized for the data preparation and generation of the result outputs.

The first test performed was the Kolmogorov-Smirnov method (implemented in software SPSS IBM Statistics 21)

Table 2 One way ANOVA

\begin{tabular}{|c|c|c|c|c|c|c|}
\hline \multicolumn{7}{|c|}{ ANOVA } \\
\hline & & SoS & $d f$ & MS & $F$ & $p$ value $^{\mathrm{a}}$ \\
\hline \multirow[t]{3}{*}{$\mathrm{Pb}$} & Between groups & 0.077 & 1 & 0.077 & 3.361 & 0.073 \\
\hline & Within groups & 1.146 & 50 & 0.023 & & \\
\hline & Total & 1.223 & 51 & & & \\
\hline \multirow[t]{3}{*}{ Co } & Between groups & 0.009 & 1 & 0.009 & 6.249 & 0.016 \\
\hline & Within groups & 0.074 & 50 & 0.001 & & \\
\hline & Total & 0.083 & 51 & & & \\
\hline \multirow[t]{3}{*}{$\mathrm{Zn}$} & Between groups & $6,749.692$ & 1 & $6,749.692$ & 86.782 & 0.000 \\
\hline & Within groups & $3,888.884$ & 50 & 77.778 & & \\
\hline & Total & $10,638.576$ & 51 & & & \\
\hline \multirow[t]{3}{*}{$\mathrm{Al}$} & Between groups & 38.960 & 1 & 38.960 & 11.129 & 0.002 \\
\hline & Within groups & 175.044 & 50 & 3.501 & & \\
\hline & Total & 214.003 & 51 & & & \\
\hline \multirow[t]{3}{*}{$\mathrm{Cd}$} & Between groups & 2.003 & 1 & 2.003 & 10.230 & 0.002 \\
\hline & Within groups & 9.790 & 50 & 0.196 & & \\
\hline & Total & 11.793 & 51 & & & \\
\hline \multirow[t]{3}{*}{$\mathrm{Cu}$} & Between groups & 28.996 & 1 & 28.996 & 11.198 & 0.002 \\
\hline & Within groups & 129.469 & 50 & 2.589 & & \\
\hline & Total & 158.465 & 51 & & & \\
\hline \multirow[t]{3}{*}{$\mathrm{Ni}$} & Between groups & 0.211 & 1 & 0.211 & 5.272 & 0.026 \\
\hline & Within groups & 1.997 & 50 & 0.040 & & \\
\hline & Total & 2.208 & 51 & & & \\
\hline
\end{tabular}

SoS sum of squares (variance), $d f$ degrees of freedom, $M S$ mean square $=$ $\mathrm{SoS} / d f, F$ test statistics $=\mathrm{MS}($ between groups)/MS(within groups), $p$ value significance

${ }^{\text {a }}$ In chemometrics, it is common to say that difference between two groups (in this case, carcinoma/healthy tissue) is statistically significant at $95 \%$ confidence interval if $p$ value is lower than 0.05
Table 3 Pearson test

\begin{tabular}{llllllll}
\hline & $\mathrm{Pb}$ & $\mathrm{Co}$ & $\mathrm{Zn}$ & $\mathrm{Al}$ & $\mathrm{Cd}$ & $\mathrm{Cu}$ & $\mathrm{Ni}$ \\
\hline $\mathrm{Pb}$ & 1.000 & & & & & & \\
$\mathrm{Co}$ & 0.087 & 1.000 & & & & & \\
$\mathrm{Zn}$ & 0.278 & 0.209 & 1.000 & & & & \\
$\mathrm{Al}$ & 0.088 & 0.319 & 0.363 & 1.000 & & & \\
$\mathrm{Cd}$ & 0.541 & -0.039 & 0.390 & 0.049 & 1.000 & & \\
$\mathrm{Cu}$ & 0.025 & 0.150 & 0.600 & 0.106 & -0.051 & 1.000 & \\
$\mathrm{Ni}$ & 0.114 & 0.385 & 0.257 & 0.581 & 0.052 & 0.195 & 1.000 \\
\hline
\end{tabular}

Table is symmetrical. Pearson $(a, b)=$ Pearson $(b, a)$

in order to investigate the normal distribution of the used data. This statistic quantifies distances between the empirical distribution function of the sample and the cumulative distribution function of the reference distribution or between the empirical distribution function of two samples. The test showed that concentrations were not normally distributed; therefore, transformation to logarithmic values was performed. The test showed the normal distribution for all element concentrations when they were presented as logarithmic values. All further calculations were performed with the original as well as logarithmic values of concentrations.

Next, a parametric analysis of variance (ANOVA) test was performed in order to find any differences in the content of studied elements between the two types of tissue. To be more precise - the available data were analysed in order to determine if statistically significant differences exist between the two sample groups (laryngeal carcinoma and healthy laryngeal tissues). The test showed that six out of seven descriptors, namely, $\mathrm{Co}, \mathrm{Zn}, \mathrm{Al} \mathrm{Cd}, \mathrm{Cu}$ and $\mathrm{Ni}$ were found to be significantly influenced by the two different types of tissue. Only $\mathrm{Pb}$ content was found not significantly different at 0.05 level of significance (see Table 2.). The lower the $p$ value is, the more confident we may be about the significance of the difference between two groups. In other words, low value of $p$ suggests that a content of a given element is different in a carcinoma tissue than in healthy one. Among the elements contained in different tissues, the following descriptors were found by

Table 4 SPEARMAN test

\begin{tabular}{llllllll}
\hline & $\mathrm{Pb}$ & $\mathrm{Co}$ & $\mathrm{Zn}$ & $\mathrm{Al}$ & $\mathrm{Cd}$ & $\mathrm{Cu}$ & $\mathrm{Ni}$ \\
\hline $\mathrm{Pb}$ & 1.000 & & & & & & \\
$\mathrm{Co}$ & 0.216 & 1.000 & & & & & \\
$\mathrm{Zn}$ & 0.277 & 0.161 & 1.000 & & & & \\
$\mathrm{Al}$ & 0.089 & 0.147 & 0.370 & 1.000 & & & \\
$\mathrm{Cd}$ & 0.387 & 0.072 & 0.441 & 0.204 & 1.000 & & \\
$\mathrm{Cu}$ & 0.134 & 0.155 & 0.592 & 0.184 & 0.093 & 1.000 & \\
$\mathrm{Ni}$ & 0.136 & 0.209 & 0.266 & 0.240 & 0.118 & 0.298 & 1.000 \\
\hline
\end{tabular}

Table is symmetrical. Pearson $(a, b)=$ Pearson $(b, a)$ 
Fig. 1 Dendrogram of the two types of tissue from 26 patients. a No data processing. b Logarithmic concentrations. Cancer-free larynx tissue (1) and carcinoma of the larynx tissue (2) (a) Ward's Method,Squared Euclidean

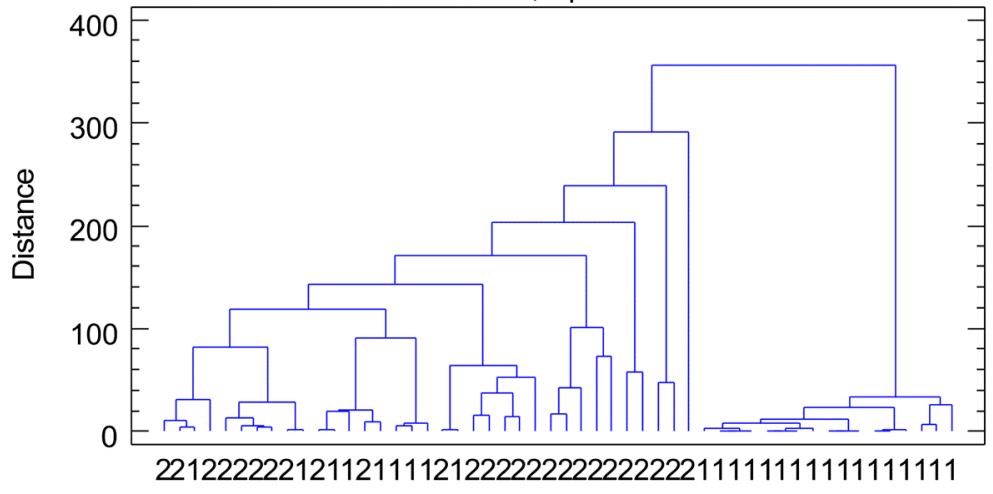

(b)

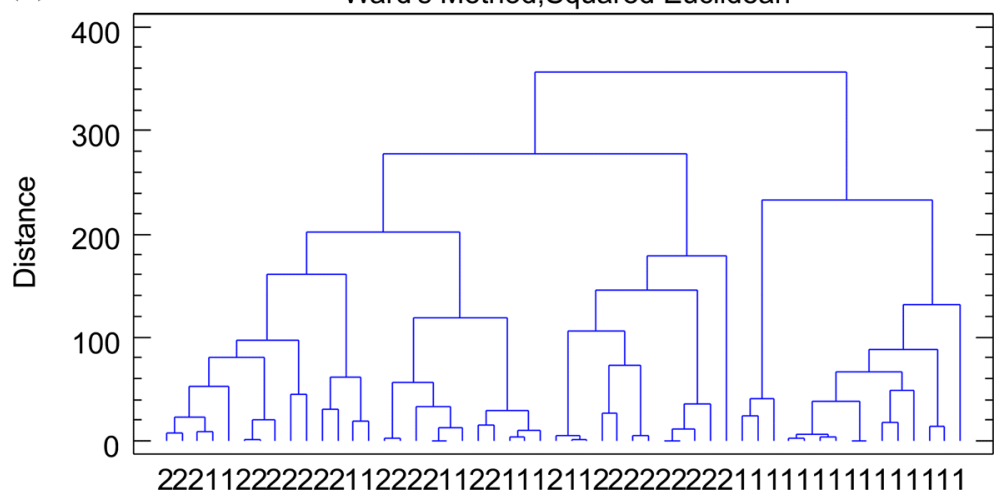

Kruskal-Wallis test significantly influenced by the group: $\mathrm{Zn}$, $\mathrm{Al}, \mathrm{Cd}$ and $\mathrm{Cu}$ with $p<0.01$ and $\mathrm{Ni}$ and Co with $p<0.05$. A summary of investigated elements complemented by the results of ANOVA and Kruskal-Wallis test considering two groups is presented in Table 2.

On the base of tests that already have been described, we may postulate that tissues could be classified as healthy or cancerous based on the measured content of seven studied elements. We are aware that such a hypothesis needs to be verified with more advanced statistical and chemometric tools. Moreover, possible correlations between descriptors should be studied. Thus, we applied additional tests and analysis that are described below in detail.

The mutual correlation coefficients between all concentrations of elements were calculated. A high value of the coefficient indicates high linear correlation between contents of two elements in a tissue. The highest correlation was observed between $\mathrm{Cu}$ and $\mathrm{Zn}$ for both parametric (Pearson) and nonparametric (Spearman) tests (Tables 3 and 4, respectively). Most of the concentrations are correlated positively; however, only few of them are correlated with a factor greater than 0.3 (in italic in Tables 3 and 4). The highest value is obtained for $\mathrm{Cu}-\mathrm{Zn}$ and is equal to 0.600 and 0.592 in Pearson and Spearman test, respectively, which means that contents of the elements are rather independent on each other.
Cluster analysis (CLU) and principal component analysis (PCA) were applied for grouping tissue samples due to measured variables.

CLU is an unsupervised multivariate statistical method. The purpose of cluster analysis is to recognize groups of objects or variables based on their similarity, which is given by the distances between the objects in the multidimensional space of the chosen variables. This analysis resulted in a dendrogram shown in Fig. 1, where two groups of tissue samples are divided into two clusters, depending on the level of similarity based on Ward distance. The greater the similarity, the smaller the distance. This feature is represented by the connected branches on Fig. 1. A well-separated group is called a cluster. In this case, one on the most most-right of Fig. 1a, b is composed only by cancer-free larynx tissue samples, while cluster on the left contains mostly carcinoma of the larynx samples.

PCA is also an unsupervised method used for analysing the structure in multivariate data sets. It is used for compressing highly dimensional and correlated data into a few uncorrelated variables. The goal of PCA is to extract the important information from the data table and express this information as a set of orthogonal variables called principal components (PC). It is used for characterization of multidimensional data, providing a satisfactory representation of the studied objects by projecting the original data set from the high-dimensional 
Fig. 2 Biplot analysis of the two types of tissues. Cancer-free larynx tissue (1) and carcinoma of the larynx tissue (2). a No data processing. b Logarithmic concentrations. The closer the points to each other, the more similar tissues are (in terms of content of the studied elements) (a)

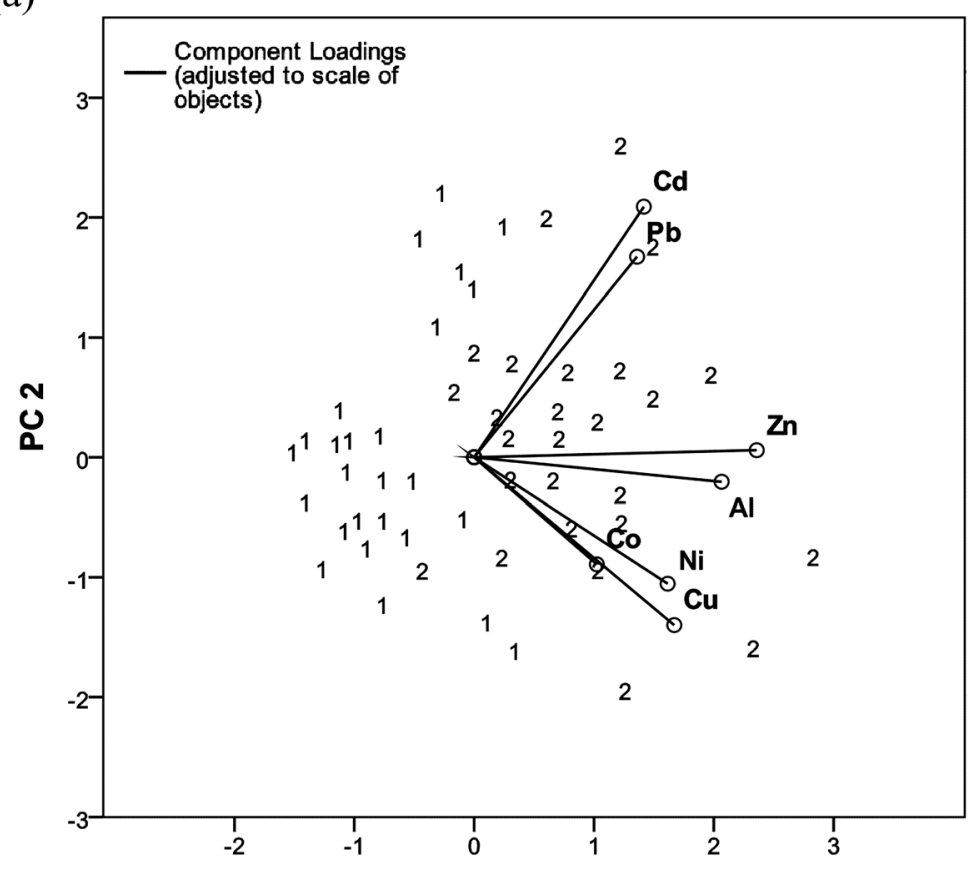

(b)

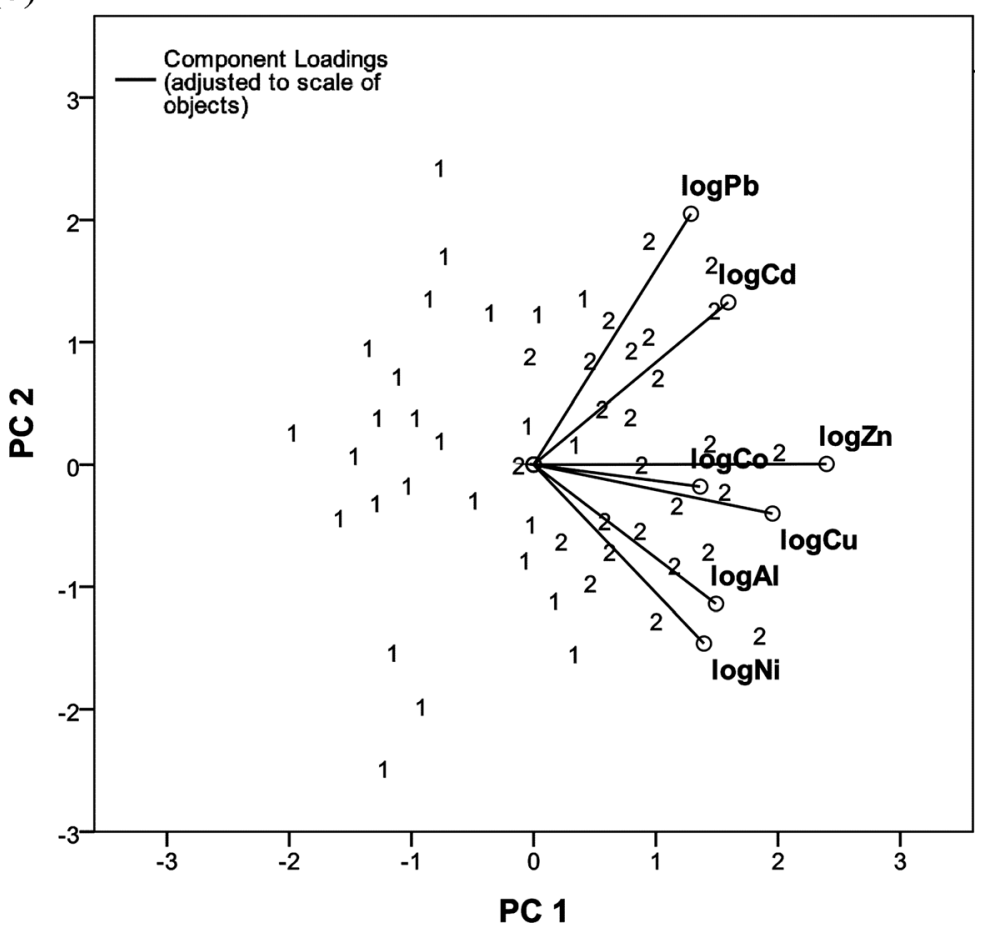

space onto the lower-dimension space. Thus, PCA can transform data from multidimensional space into two dimensions without losing a considerable amount of information. With the PCA biplot, one can simultaneously demonstrate the objects (in this case, tissue samples) and the variables (contents of the elements). It is also possible to detect those variables, which are associated with the formed group of closely located objects, which means that the mutual relationships among the objects and variables can be discovered [20-22]. For the record and clarity, in this study, PCA was performed in order to obtain an overall impression about the correlation of the two types of tissues (laryngeal carcinoma and healthy laryngeal tissue) obtained from 26 patients. It was applied to the matrix composed of $52 \times 7$ elements. Fifty-two rows represented the tissue samples composed of seven variables. The tissue samples are characterized by the concentration of $\mathrm{Pb}, \mathrm{Co}, \mathrm{Zn}, \mathrm{Al}$ 
Fig. 3 Graphical output of LDA for the 52 tissue samples that are separated in two clusters: Cancerfree larynx tissue ( 1 ) and carcinoma of the larynx tissue (2). a No data processing. $\mathbf{b}$ Logarithmic concentrations. The closer the points to each other, the more similar tissues are (in terms of content of the studied elements) (a)

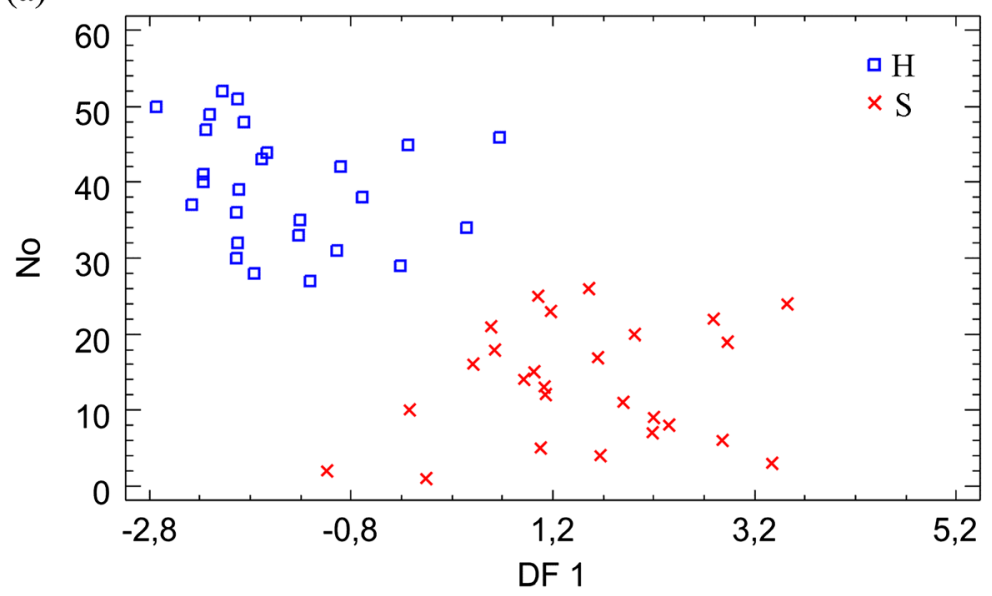

(b)

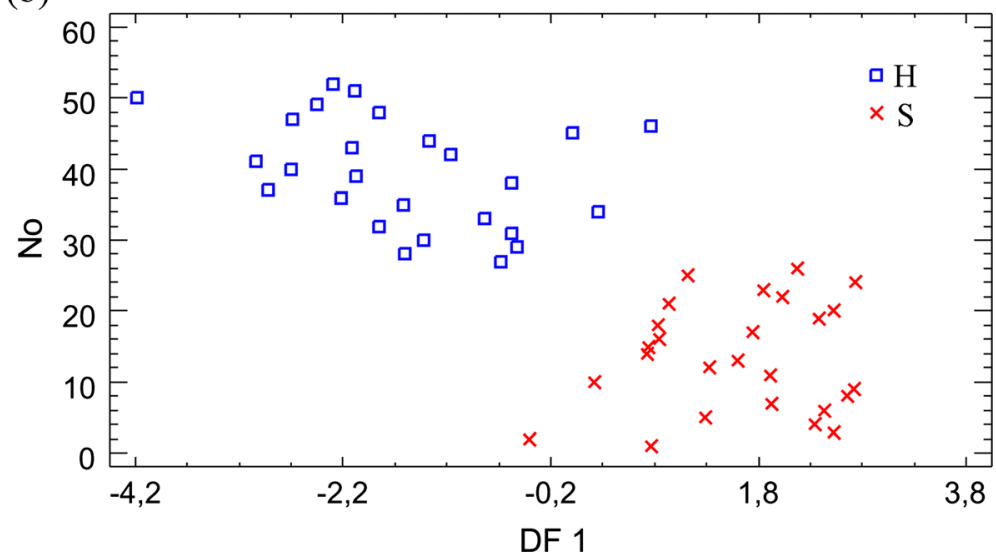

$\mathrm{Cd}, \mathrm{Cu}$ and $\mathrm{Ni}$. The enumerated variables are components of the vector representation of each tissue sample that is used in further chemometric analysis. Each patient was described with two samples, one carcinoma of the larynx tissue and one cancer-free larynx tissue. Moreover, the data were additionally

Table 5 Classification results for 52 tissue samples into predicted groups Classification results

\begin{tabular}{|c|c|c|c|c|c|}
\hline & & & \multicolumn{2}{|c|}{ Predicted group membership } & \multirow[t]{2}{*}{ Total } \\
\hline & & & $H$ & $C$ & \\
\hline \multirow[t]{4}{*}{ Original } & Count & $H$ & 24 & 2 & 26 \\
\hline & & $C$ & 3 & 23 & 26 \\
\hline & $\%$ & $H$ & 92.3 & 7.7 & 100.0 \\
\hline & & $C$ & 11.5 & 88.5 & 100.0 \\
\hline \multirow[t]{4}{*}{ Cross-validated } & Count & $H$ & 23 & 3 & 26 \\
\hline & & $C$ & 3 & 23 & 26 \\
\hline & $\%$ & $H$ & 88.5 & 11.5 & 100.0 \\
\hline & & $C$ & 11.5 & 88.5 & 100.0 \\
\hline
\end{tabular}

$H$ healthy tissue, $C$ cancer tissue preprocessed before PCA. Column standardization of individual variables was performed. In this procedure, the mean of the column elements is subtracted from individual elements and divided by the column standard deviation. Consequently, each column has zero mean and unit variance.

Table 6 Classification results for 52 tissue samples into predicted groups using logarithmic concentration values of seven elements

Classification results

\begin{tabular}{|c|c|c|c|c|c|}
\hline & & & \multicolumn{2}{|c|}{ Predicted group membership } & \multirow[t]{2}{*}{ Total } \\
\hline & & & $H$ & $C$ & \\
\hline \multirow[t]{4}{*}{ Original } & Count & $H$ & 23 & 3 & 26 \\
\hline & & $C$ & 1 & 25 & 26 \\
\hline & $\%$ & $H$ & 88.5 & 11.5 & 100.0 \\
\hline & & $C$ & 3.8 & 96.2 & 100.0 \\
\hline \multirow[t]{4}{*}{ Cross-validated } & Count & $H$ & 22 & 4 & 26 \\
\hline & & $C$ & 2 & 24 & 26 \\
\hline & $\%$ & $H$ & 84.6 & 15.4 & 100.0 \\
\hline & & $C$ & 7.7 & 92.3 & 100.0 \\
\hline
\end{tabular}

$H$ healthy tissue, $C$ cancer tissue 
The results showed that $52.41 \%$ of variance was explained in the first two principal components of the transformed data. It was evident that a considerable amount of information still remains by keeping only the first two principal components. Figure 2 shows the biplot (PC1 vs. $\mathrm{PC} 2$ ) resulting from PCA of the carcinoma larynx tissues and cancer-free larynx tissues represented with seven variables. This plot displays the positions of the two types of tissue as well as all variables. It can be seen that the first principal component $\mathrm{PC} 1$ was mainly associated with $\mathrm{Zn}$ and $\mathrm{Al}$ concentration which are positively correlated. The second component PC2 mainly represented the descriptors $\mathrm{Cd}$ and $\mathrm{Pb}$ also showing their positive correlation. We must additionally point out that, from Fig. 2, the grouping is evident. PCA for those tissue samples, distributed within the region of larger PC1 and also the PC2 values, were samples labelled as number 2 (carcinoma of the larynx tissue). The first cluster on the left contains samples labelled as number 1 (cancer-free larynx tissue). The samples labelled with 1 are well separated from the samples labelled with 2 (carcinoma of the larynx tissue). Results are in concordance with ANOVA and KruskalWallis test and show significant differences between two types of tissue.

Linear discriminant analysis (LDA) is a supervised pattern recognition method in which a classification model is constructed using the data of the objects precategorized into known categories. The calculation algorithm of LDA is trained to discriminate the objects into the given categories (classes). It is based on the determination of linear discriminants, which maximize the ratio of between-class variance and minimize the ratio of within-class variance. LDA is considered to be a dimension reduction method. For feature reduction, it is necessary to determine a smaller dimension hyper plane on which the points will be projected from the higher dimensional space. LDA selects directions, which achieves maximum separation among the given classes [22]. The calculations were performed using the software IBM SPSS Statistics 21. The validation of the LDA model was accomplished by the leave-one-out method. Altogether, 52 tissue samples were divided into two types: (1) cancer-free larynx tissue and (2) carcinoma of the larynx tissue.

We found out that two well-separated clusters were evident from Fig. 3. The first cluster (1) is cancer-free larynx tissue and the second one (2) is carcinoma of the larynx tissue. Classification results for two types of tissue are presented in Tables 5 and 6. LDA classification rate was $88.5 \%$ for the cross validation data for both original and logarithmic values of the elements' concentration. In other words, we may say that tissue can be classified as healthy/cancerous with approximately $88 \%$ accuracy, based only on the content of studied elements.
We strongly believe that presented analysis allows us to state that tissue can be classified as carcinoma or cancer-free based on the concentration of elements studied in this paper.

\section{Conclusion}

Several chemometric methods for the evaluation and classification of the two types of studied tissues were applied. These methods seem to be a very useful tool for a visualization of a multivariate data and to enable quick classifications of the tissue samples, in regard to the content of trace elements. From the statistic point of view, the contents of studied metals for samples of healthy and cancerous tissues are not normally distributed; however, normal distribution was confirmed for $\log$ values. Additionally, it was found that there is a statistically significant difference in concentrations of $\mathrm{Zn}, \mathrm{Cd}, \mathrm{Cu}$ and $\mathrm{Al}(p<0.01)$ and $\mathrm{Ni}$ and $\mathrm{Co}(p<0.05)$ when healthy tissue is compared to cancerous one; in the case of $\mathrm{Pb}$, the difference is not statistically significant. Although the correlation between elements content is usually positive, the highest was found between $\mathrm{Zn}$ and $\mathrm{Cu}$; however, neither in the Pearson test nor in the Spearman test, the value did not exceed 0.6. In most cases, tissues may be successfully classified as carcinoma or larynx free, based on the content of studied elements. We confirmed this fact by numerous statistical methods (CLU, ANOVA, LDA, PCA).

In conclusion, the statistic data confirmed that there is a difference in the trace metal levels in laryngeal cancer tissues as compared to healthy laryngeal ones. This phenomenon may be due to the changed cellular metabolism in the cancer development process. Further investigation is needed; however, if the levels of trace metals in cancerous and healthy tissues prove to be consistently different, it may provide a simple tool for differentiating both types of tissues. Most promising for use as the indicators are $\mathrm{Al}$ and $\mathrm{Zn}$, which exhibit the greatest differences in their content between both types of tissue.

Acknowledgments The authors are grateful to Professor Dr. Joseph H. Rule from Old Dominion University (Norfolk, VA, USA) and his wife Dr. Anna M. Rule for their help with the English preparation of the manuscript.

Open Access This article is distributed under the terms of the Creative Commons Attribution License which permits any use, distribution, and reproduction in any medium, provided the original author(s) and the source are credited.

\section{References}

1. Durak L, Kavutcu M, Canpolat O, Ișik AU, Akyoglu Ö (1994) Concentration of some major and minor elements in larynx tissues with and without cancer. BioMetals 7:45-48

2. Beisel WR (1982) Single nutrient and immunity. Am J Clin Nutr 35: $417-468$ 
3. Fraker PJ, Gershwin ME, Good RA, Prasada A (1986) Interrelationship between zinc and immune system. Fed Proc 45: 1417-1479

4. Taysi S, Akcay F, Uslu C, Dogru Y, Gulcin I (2003) Trace elements and some extracellular antioxidant protein levels in serum of patients with laryngeal cancer. Biol Trace Elem Res 91:11-18

5. Klatka J, Remer M, Dobrowolski R, Pietruszewska W, Trojanowska A, Siwiec H, Charytanowicz M (2011) The content of cadmium, cobalt and nickel in laryngeal carcinoma. Arch Med Sci 3:517-522

6. Vural H, Uzun K, Uz E, Kocyigit A, Cigli A, Akyol O (2000) Concentration of copper, zinc and various elements in serum of patients with bronchial asthma. J Trace Elem Med Biol 14:88-91

7. Cesura S, Kocaturkb PA, Kavasb GO, Aksarayc S, Tezerenc D, Ciftcid U (2005) Serum copper and zinc concentrations in patients with brucellosis. J Infect 50:31-33

8. Cebeci SA, Kavas GO, Yilmaz N, Buyukkagnici DI (2005) Serum copper and zinc concentrations in patients with chronic hepatitis C. J Infect 51:35-37

9. Arita A, Costa M (2009) Epigenetics in metal carcinogenesis: nickel, arsenic, chromium and cadmium. Metallomics 1:222-228

10. Salnikov K, Zhitkovich A (2008) Genetic and epigenetic mechanism in metal carcinogenesis and cocarcinogenesis: nickel, arsenic and chromium. Chem Res Toxicol 21:28-44

11. Oller AR, Costa M, Oberdorser G (1997) Carcinogenicity assessment of selected nickel compounds. Toxicol Appl Pharmacol 143:152-166

12. Trott DA, Cuthbert AP, Overell RW, Russo I, Newbolt RF (1995) Mechanisms involved in the immortalization of mammalian cells by ionizing radiation and chemical carcinogens. Carcinogenesis 16:193204
13. Goldberg P, Leclerc A, Luce D, Morcet J, Brugere J (1997) Laryngeal and hypopharyngeal cancer and occupation: results of a case-control study. Occup Environ Med 54:477-482

14. Feinberg A, Oshiimura M, Barret J (2000) DNA methylation: past, present and future directions. Carcinogenesis 21:461-467

15. Doll R, Morgan LG, Speizer FE (1970) Cancers of the lung and nasal sinuses in nickel workers. Br J Cancer 24:623-632

16. Sen P, Costa M (1985) Induction of chromosomal damage in Chinese hamster ovary cells by soluble and particulate nickel compounds: preferential fragmentation of the heterochromatic long arm of Xchromosome by carcinogenic crystalline NiS particles. Cancer Res 45:2320-2325

17. Waalkes M (2003) Cadmium carcinogenesis. Mutat Res 533:107120

18. Takiguchi M, Achanzar WE, Qu W, Li G, Waalkes MP (2003) Effects of cadmium on DNA-(cytosine-5) methyltransferase activity and DNA methylation status during cadmium-induced cellular transformation. Exp Cell Res 286:355-365

19. Linder MC (2012) The relationship of copper to DNA damage and damage prevention in humans. Mutat Res 733:83-91

20. Linsinger T (2010) ERM application note 1. European Commission Joint Research Centre Institute for Reference Materials and Measurements (IRMM), Geel

21. Massart DL, Vandeginste BGM, Buydens LMC, De Jong S, Lewi PJ, Verbeke JS (1997) Handbook of chemometrics and qualimetrics: part A. Elsevier, Amsterdam

22. Varmuza K, Filzmoser P (2008) Introduction to multivariate statistical analysis in chemometrics. CRC Press, Boca Raton

23. Brereton RG (2003) Chemometrics, data analysis for the laboratory and chemical plant. John Wiley \& Sons, Ltd, Chichester 